\title{
CLUTCH-BRAKE UNIT - PRINCIPLE OF OPERATION AND BASIC DIAGNOSTIC METHODS
}

\author{
Krzysztof ROCZEK ${ }^{1}$, Adrian KROL ${ }^{2}$ \\ ${ }^{1}$ General Motors Manufacturing Poland, Krzysztof.roczek@gm.com \\ ${ }^{2}$ General Motors Manufacturing Poland, Adrian.krol@gm.com
}

\begin{abstract}
Clutch-Brake system is one of the most important element of mechanical press line. The main purpose of it is to transmit the torque from the electric motor and flywheel to gear and main shaft. It ensures slide motion, but also press safety. One of the parameter that needs to be measured periodically is overrun. This value directly shows what is the condition of clutch-brake unit. The longer overrun, the worse brake operation. Unfortunately this one does not show what is the root cause of that situation. From that reason it is necessary to perform deeper diagnosis of complete system. One may find out from this article how to check clutch-brake unit in details- how to correlate slide position and slide speed with hydraulic pressure and position of safety valve (PSV).
\end{abstract}

Keywords: clutch-brake unit, diagnostic methods, operation

\section{ZESPÓŁ SPRZĘGLO-HAMULEC - ZASADA DZIAŁANIA ORAZ PODSTAWY DIAGNOSTYKI}

\section{Streszczenie}

Układ sprzęgło-hamulca jest jednym z najważniejszych elementów mechanicznej linii pras. Głównym jego zadaniem przeniesienie momentu obrotowego $z$ silnika i koła zamachowego do przekładni i wału głównego. Realizuje on ruch suwaka, ale również zapewnia bezpieczeństwo prasy. Jednym z parametrów, jakie muszą być okresowo sprawdzane jest wybieg. Jego wartość dobrze obrazuje aktualną kondycję układu sprzęgło-hamulca. Dłuższy wybieg, gorsze działanie hamulca. Niestety sam wybieg nie wskazuje przyczyny źródłowej takiej sytuacji. $\mathrm{Z}$ tego powodu niezbędne jest wykonanie głębszej analizy całego układu. Z poniższego artykułu można się dowiedzieć jak dokładnie sprawdzić sprzęgło-hamulec- jak skorelować wartości pozycji oraz prędkości suwaka z ciśnieniem w układzie hydraulicznym i pozycją zaworu PSV.

Słowa kluczowe: układ sprzęgło-hamulec, metody diagnostyczne, użytkowanie

\section{INTRODUCTION}

Press lines utilized in automotive industry are the first step in cars manufacturing process. This kind of machines stamps successive elements of car body with high forces on level $20000 \mathrm{kN}$.

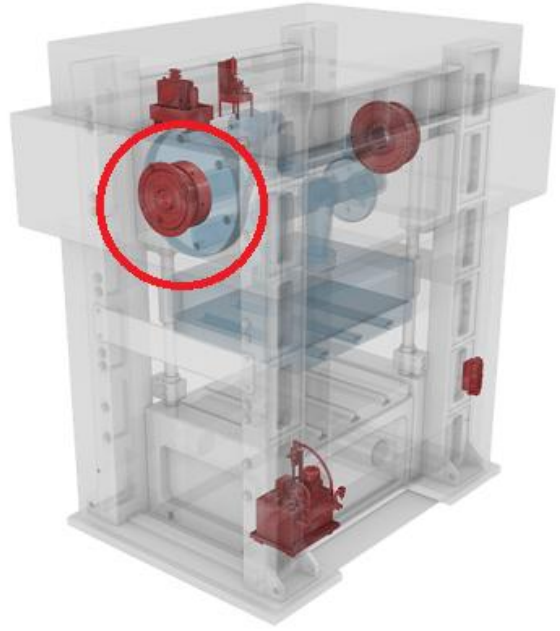

Fig. 1.1. Clutch-Brake on automotive stamping press
They are supplied through gears and flywheel by the main drive. The element that connects the main drive and flywheel and transmits a torque to main shaft is a clutch-brake unit.

Due to the fact that breakdowns of the C-B elements can be extremely expensive and time consuming, it is necessary to know the principle of operation and diagnostic methods of that unit. In this article we will concentrate on hydraulic clutchbrake operation and diagnostic methods.

\section{RESEARCH OBJECT}

The Clutch-Brake system that was analyzed is a part of $22000 \mathrm{kN}, 5-$ station transfer press utilized in automotive industry. The complete hydraulic CB unit is supplied from external hydraulic aggregate. The aggregate provides hydraulic pressure needed for clutching activation. Due to safety reasons, normally the unit is in breaking position. It is ensured by mechanical springs that are installed inside of C-B. Then even if there is a power loss or an aggregate failure appear, slide motion is deactivated. Fig.1.2 presents simplified 
construction of C-B unit. In general one may distinguish two modes of operation: clutching and breaking. In case of breaking, spring (1) acts on

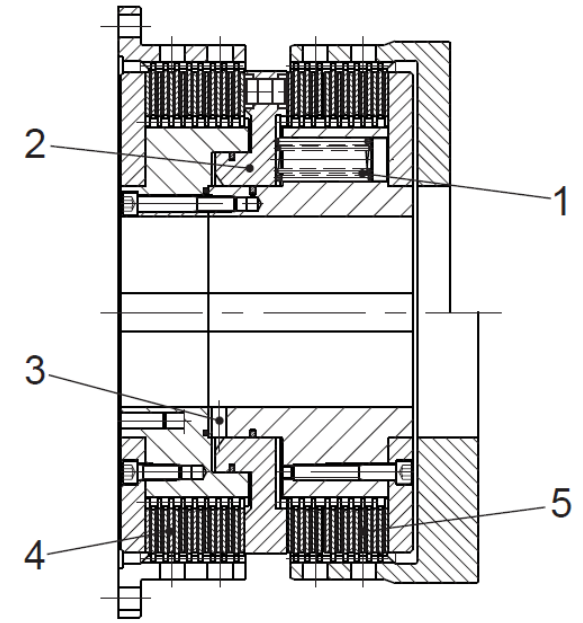

Fig. 1.2. Simplified construction of C-B unit 1-Spring, 2- Piston, Hydraulic Oil, 4- Brake plates, 5- Clutch plates

piston (2) in the cylinder. This results in friction connection between breaking plates. In case of clutching, hydraulic oil acts against the force of mechanical spring and frictional connection between clutching plates is performed.

One may notice that proper operation of C-B unit is crucial for both: safety and production stability. For that reason it is important to know how to diagnose the $\mathrm{C}$-B unit.

One of the method is checking the air gap that appears as a result of plates wear during operation.

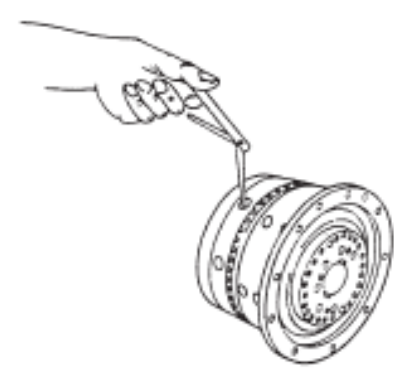

Fig. 1.3. Clutching air gap measurement

Fig.1.3 and 1.4 presents the gap measurement points. It is necessary to use the openings in C-B housing and then to screw in a measurement rod. The rod will move during clutching or breaking activation. The distance of movement will indicate the breaking and clutching plates wear level. Normally it is placed in a range of $1,8 \mathrm{~mm}$ to $4,8 \mathrm{~mm}$ depending on the number plates and built dimension. Additionally, it is important to remember that if the measurement is performed on a transfer press with common shaft for all steps, press slides must be well balanced. The angle of successive slides stop depends on angle shift between first and rest of operations as well as on differences in slides weights. To decrease influence of weight, the test should be done without dies. In case the slides will be poorly balanced, clutching activation will cause that clutch will rotate (due to gravity force that acts on poorly balanced slides) and damage the measurement rod. In the worst case the rod will be pulled in under the C-B housing and dismantling of housing will be necessary. For single presses slides should be positioned in bottom dead center point.

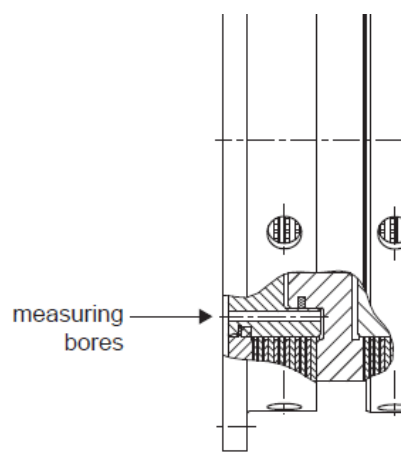

Fig. 1.4. Braking air gap measurement

More advanced method of C-B diagnosis is checking the operation of complete system. For that purpose the following equipment is required:

- Pressure sensor (ie. Balluff BSP00FT, 0-100 bar, 4-20mA)

- Tool for overrun measurement- speed and displacement monitoring (with data output)

- Connection to PSV (Pressure Safety Valve)

- Oscilloscope

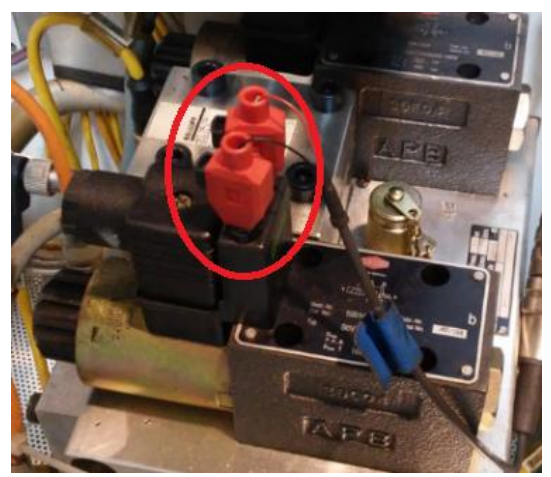

Fig. 1.5. Connection to the coil of PSV

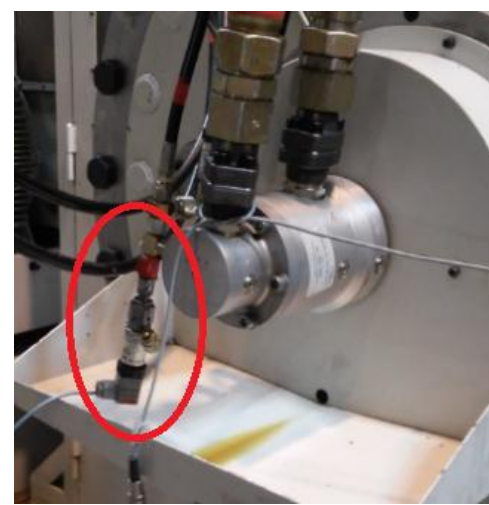

Fig. 1.6. Connection of pressure sensor to $\mathrm{C}-\mathrm{B}$ unit 


\section{MEASUREMENT RESULTS}

During complete measurement different press speeds should be tested (i.e. 7, 9, 11, 13, 15, 17 SPM). For each of them two different stop types should be performed: soft breaking (End Of Cycle) and hard breaking (Emergency Stop). The historical data from analysis of C-B unit working is presented on fig. 1. This graph shows data from 2009. The older data are not available. Estimated time soft breaking was about $400 \mathrm{~ms}$

The plots of worn Clutch- Brake unit operation is presented on fig. 1.8. The total time of braking extended to about $900 \mathrm{~ms}$. This extension by many things. The C-B that was analyzed here is a unit that operates on transfer press line. Table 1.1 presents basic data of analyzed C-B. Based on the torque in unit, even small deterioration of the device may have a huge impact on the braking distance. Shorter time and consequently shorter braking distance decreases possibility of damage other parts of press line like transfers.

Table 1.1. Basic analyzed C-B unit data

\begin{tabular}{|c|c|c|c|c|}
\hline $\begin{array}{c}\text { Operating } \\
\text { pressure } \\
{[\text { bar }]}\end{array}$ & $\begin{array}{c}\text { Number } \\
\text { of friction } \\
\text { surfaces }\end{array}$ & $\begin{array}{c}\text { Torque } \\
{[\mathbf{N m}]}\end{array}$ & $\begin{array}{c}\text { Rotation } \\
\text { per } \\
\text { minute }\end{array}$ & $\begin{array}{c}\text { Outer } \\
\text { diameter } \\
{[\mathbf{m m}]}\end{array}$ \\
\hline $87^{+5}$ & 24 & 600000 & 1700 & 1180 \\
\hline
\end{tabular}

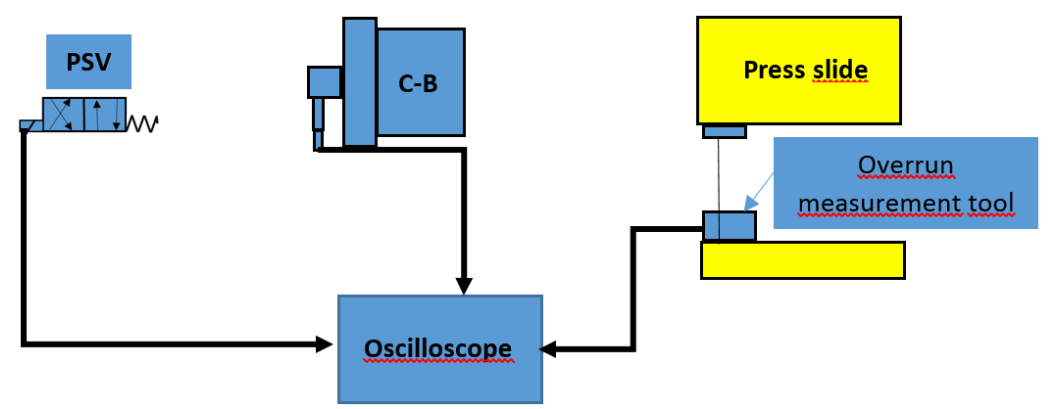

Fig. 1.7. Connection diagram for C-B diagnosis

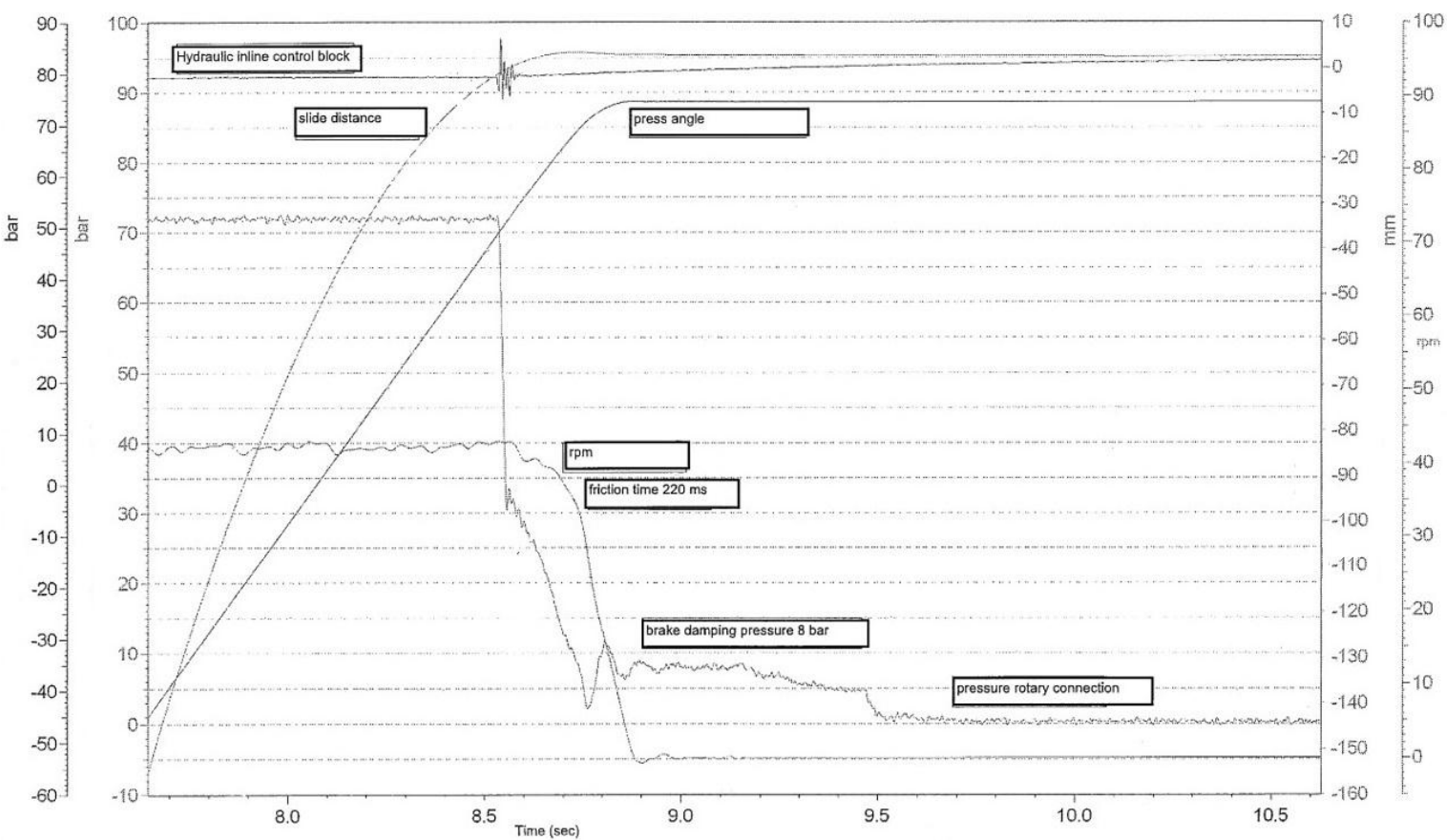

Fig. 1.8. Plot of C-B unit breaking with End Of Cycle (soft breaking) mode at 7 SPM in 2009 


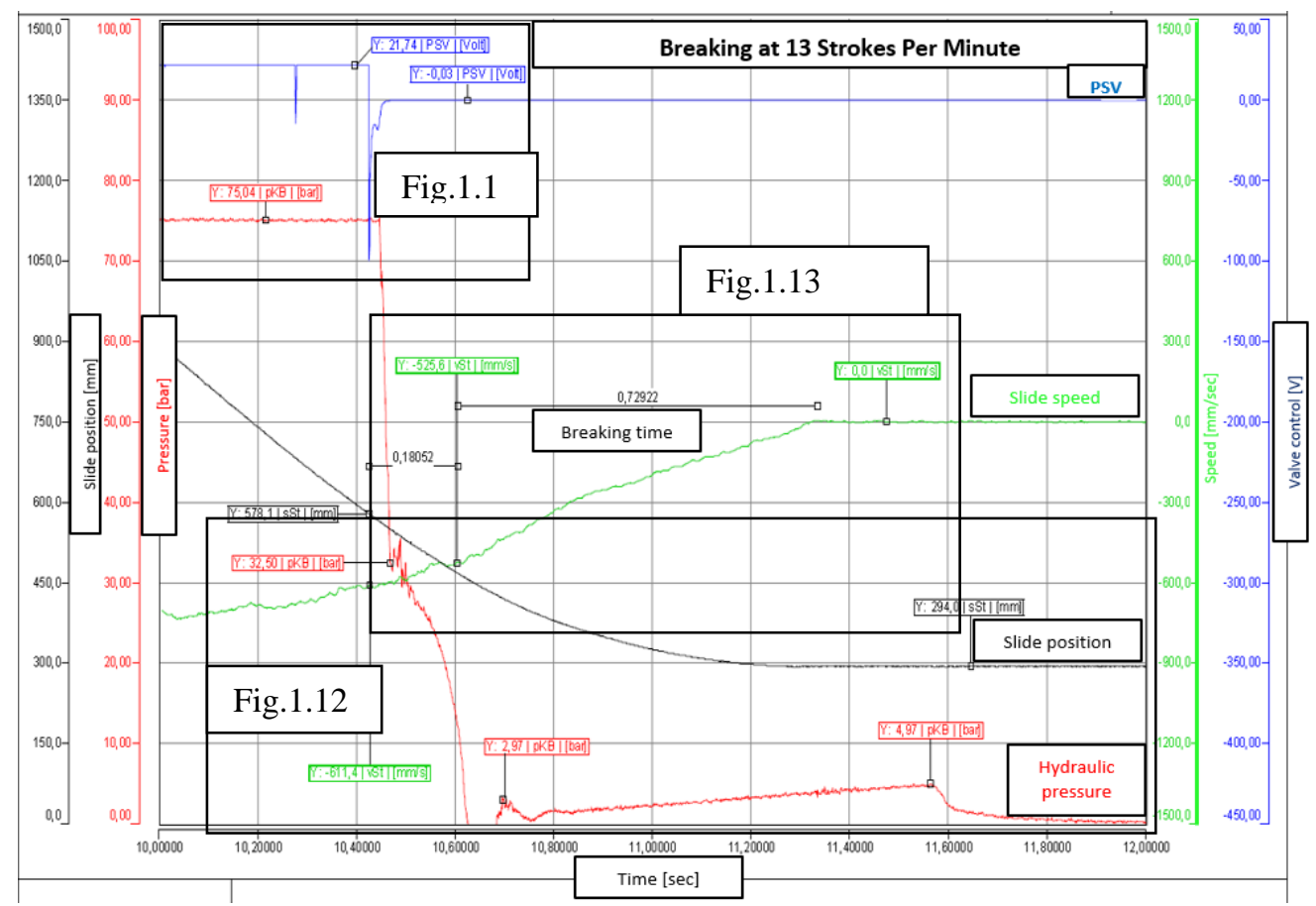

Fig. 1.9. Plot of worn C-B unit breaking with End Of Cycle (soft breaking) mode at 13 SPM

\section{PROBLEM ANALYSIS}

One may find below detailed analysis of problems that can be visible on Fig. 1.12.

\subsection{PSV VALVE AND PRESSURE REACTION ANALYSIS (END OF CYCLE)- WITHOUT DIES - 13 SPM}

Blue plot presents deactivation of PSV valve, what means- request of breaking (pick down). PSV valve releases the pressure from system in normal state, means if there is no power connected or there is a power supply breakdown, the system is breaking. To active clutch it is necessary to activate PSV valve and supply the system with hydraulic pressure, so that springs are compressed and clutching is performed.

Here one can see that the pressure (red) started to decrease with delay (about 20ms) to the valve deactivation. This is caused by operation of valve itself. Magnetic field must be built, piston must react on it, this takes those $20 \mathrm{~ms}$. So, this kind of delay can be treated as proper operation.

Fig. 1.12. Analysis of hydraulic preasure during braking

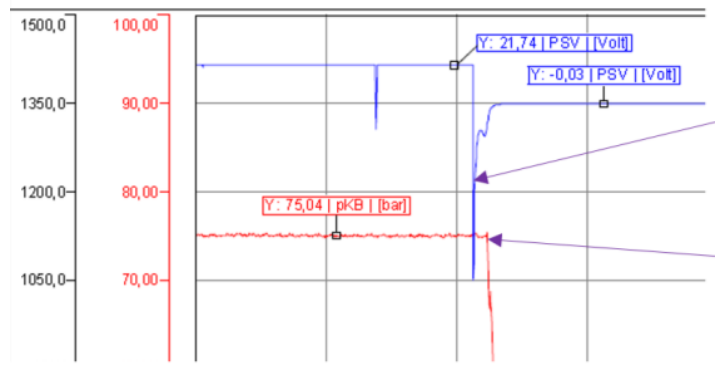

Fig. 1.10 Analysis of valve reaction
This kind of disturbance (red) is related to spring activation in CB unit. So, the force coming from the oil pressure $(32,50$ bar) started to be lower that the force of spring. The forces vectors have the same direction, but opposite senses. The spring was released and this caused disturbance in pressure value. Spring pushed the oil and pressure increased a bit in uncontrolled way. By number 1 a final pressure during breaking is marked. According to hydraulic diagram it was noticed that the pressure is set to value of 7 bar. So, after deactivation of PSV valve, the pressure should drop down to 7 bars and keep this value constant. Unfortunately, the pressure is disturbed $(2,97$ bar $)$ at the beginning and is not constant, but increases its value. The final value is equal to 4,97 bar, so is below the standard (7 bar). This is NOK.

On the other hand lower pressure during soft breaking should cause faster line stop. The force of spring does not change. It is only dependent on the spring length $(\mathrm{F}=-\mathrm{kx}, \mathrm{k}$-spring constant, $\mathrm{x}$ length of spring), but in spite of that if the opposite pressure is lower, the plates should be squeezed harder, to the braking force should be higher (Fig. 1.11).

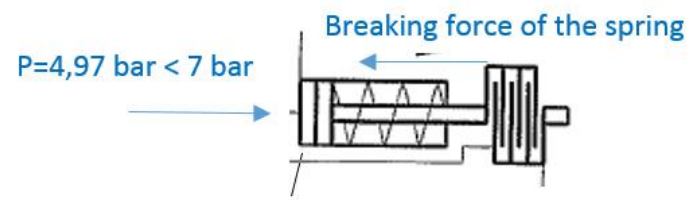

Fig. 1.11. Breaking 


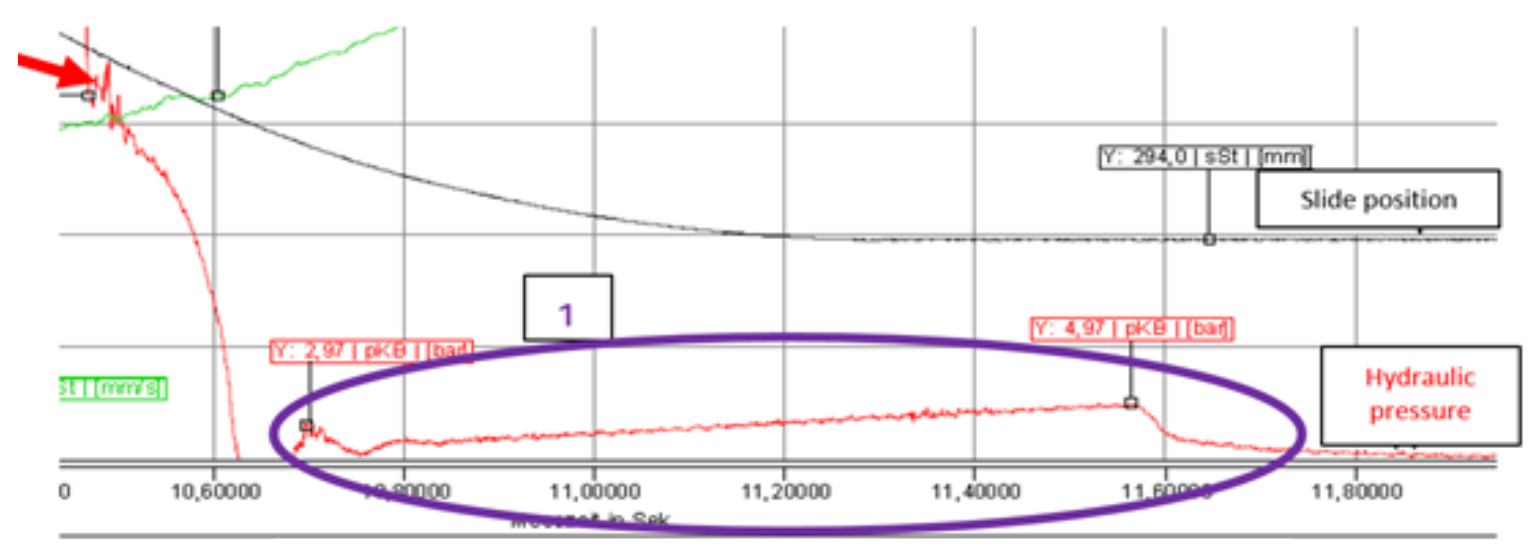

Fig. 1.12. Analysis of hydraulic pressure during braking

\section{Remark}

The pressure equal to 7 bar is defined to decrease the force of breaking and to decrease impact forces that appears then on the machine. It is obvious that if the pressure would be equal to 0 bar, the force of breaking would be very high what has negative influence on the machine mechanics. On the other hand this pressure is decreased to 0 bar in case of emergency stop.

\subsection{SLIDE BRAKING ANALYSIS (END OF CYCLE) - WITHOUT DIES - 13 SPM}

The total time between deactivation of PSV valve and slide stop is equal to $909 \mathrm{~ms}$. The time equal to $180 \mathrm{~ms}$ is the time when slide is still moving with its initial speed (full speed before start of breaking). For that time the breaking plates don't touch each other (pressure is too high). The breaking starts when the pressure is decreased to about 15 bars. The time of breaking itself takes $729 \mathrm{~ms}$. Slide breaking is marked by violet. The slope of breaking curve changes at about $300 \mathrm{~ms}$. This behavior is improper because it increases the breaking time by about $200 \mathrm{~ms}$.

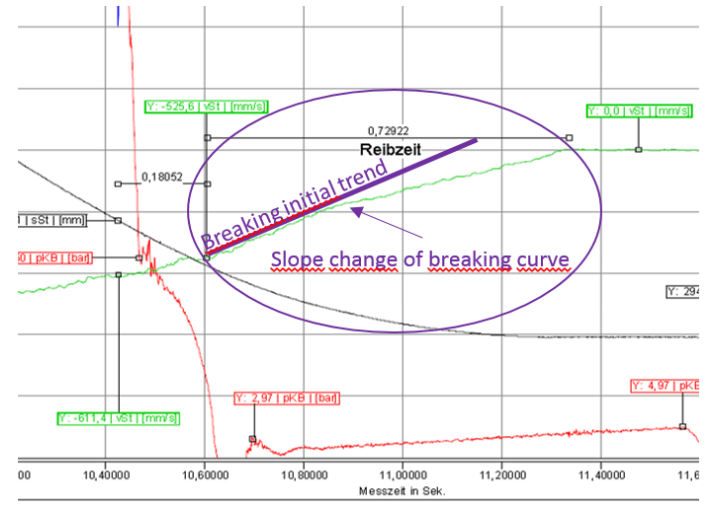

Fig. 1.13. Slope change of breaking curve

\subsection{SLIDE BREAKING ANALYSIS (EMERGENCY STOP) - WITHOUT DIES - 13 SPM}

As it was already mentioned it is always good to perform also a test of hard breaking. One may say that this kind of test is the most important for C-B operation due to safety reasons For presses that can operate with safety fences opened, overrun is the most important safety parameter that must be checked every year. In case of this analysis, the test was done to check operation of C-B unit. The press line is closed by safety fences and it is impossible to run the slide with safety gate opened. Fig. 1.10 shows exactly operation of C-B unit in case of emergency stop.

\subsection{PRESSURE REACTION ANALYSIS}

Plot on the right hand side presents the pressure and slide speed. The main difference here (in comparison to soft breaking) is the pressure level. One can see that the pressure drops down to value of 0 bars directly. This ensures maximum squeezing of the breaking plates and in consequences, maximum breaking force. The pressure disturbance coming from the spring activation is on the same level as in case of soft breaking (about 31 bars). The slope of slide speed curve negligibly differs along breaking period. In spite of that one can see that the breaking time is equal to about $586 \mathrm{~ms}$ what is twice original value.

Additionally gap measurements were performed. For both cases- clutching and breakingthe results are according to standard.

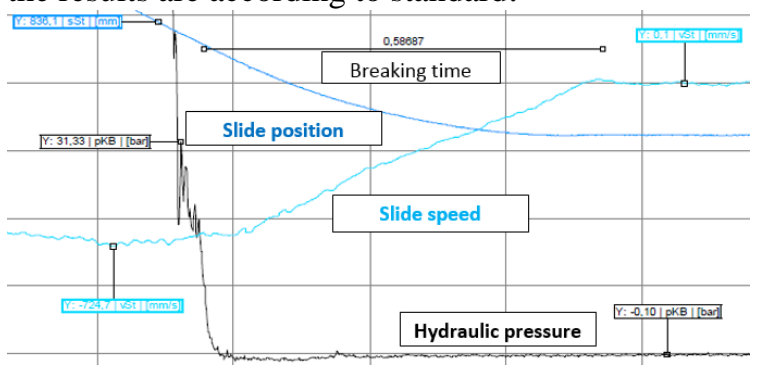

Fig. 1.14. Pressure reaction during emergency stop 


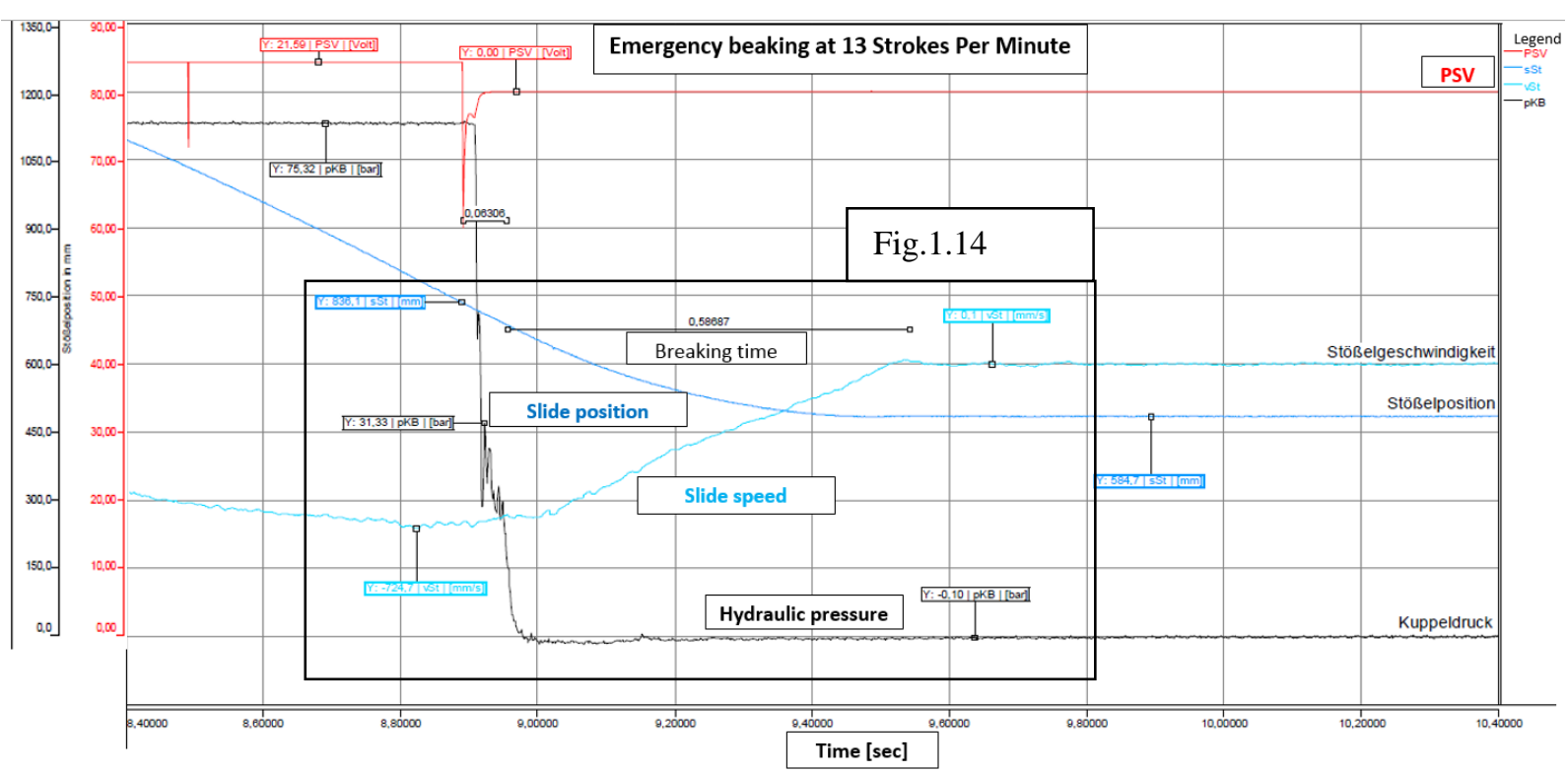

Fig. 1.15. Plot of C-B unit breaking with Emergency Stop mode

\section{PROPOSITION OF DIAGNOSTIC METHOD}

To check the condition of the unit we have to develop the simply method to monitoring times of individual characteristic parts of signals like value decrease or determination of the value at the specific level. C-B unit condition monitoring method is based on analysis value of parameters after certain time since trigger. The trigger is defined as input signal to PSV that causes braking start. Based on the historical data we was able to define the time after that the signal reaches expected value. When this time is exceeded the warning is shown. The expected values are mean as the limit or as the range of values. During every stop the analysis can be performed. Proposed method on this stage of development do not check the slope of plot or other characteristic features of signal. Monitoring e.g. slope of slide velocity signal may do not have sense. Main reason for that is the different initial value of signal. The speed of slide is heavily dependent on position of press during braking start. When the slide is in upper or lower boundary position its speed is lowest but in the middle of its route the velocity is highest. We do not know yet how the position of press at the beginning of braking effect on overall time to slide stop. On this stage of development we try to implement this system on real object and gathering data. More accurate results from this system we presents you in nearest opportunity. In the future this method will be expanded by more complex methods of signal analysis such as trend tracking or determination of falling/rising edges of signals. Fig.1.16 presents proposal of diagnostic system written in pseudocode. It also shows relations between successive variables.

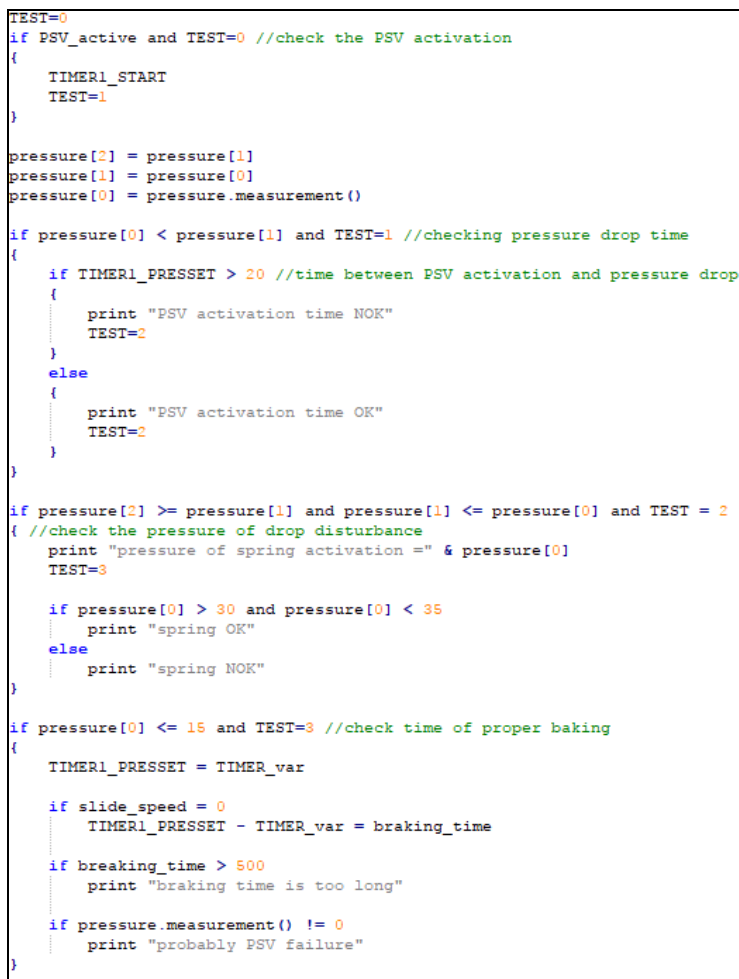

Fig1.16. Pseudocode of diagnostic system

\section{CONCLUSIONS}

The Clutch-Break unit requires renovation and plates replacement. Independently on plates thickness it seems that the friction surface is worn. The second thing that has to be checked is hydraulic unit that provides improper oil pressure in case of soft breaking.

In some cases, the gaps measurement result suggests that the plates thicknesses are according to standard, but in spite of that one may observe that operation of C-B doesn't work. From that reason it 
is always good to perform deep analysis to identify major problems with operation.

Proposition of method allow to determine improper operation of C-B unit. Longest time and in consequence longest braking distance can cause problems with collisions of slide with other elements of line like robot's arm handling the prefabricate. Damages of some elements of press line or even a die are very expensive and cause long break time. Time monitoring method allow to detect of early symptoms of C-B degradation and maintenance will able to plan the repair or replace of C-B which will reduce the break time to minimum.

\section{REFERENCES}

1. Junge C, Ruhland T, Gruber S, Wegener R, Soter S. Controlled Input-Output-Shaft Synchronisation by a Linear Drive actuated Hydraulic Clutch-BrakeCombination. The Falls Resort and Conference Centre, Livingstone, Zambia, 2011. http://ieeexplore.ieee.org/stamp/stamp.jsp?arnumber= 6072185

2. Junge C, Gallep J, Wegener R, Soter S. Simulation and Verification of an Eccentric Press System Actuated by Hyraulic-Clutch-Brake-Combination controlled by a Linear Drive. IEEE Region 8 SIBIRCON 2010: 800-805.

http://ieeexplore.ieee.org/stamp/stamp.jsp?arnumber= $\underline{5555087}$

3. Junge C, Gruber S, Budschun F, Soter S. System Analysis and Optimization of a Pressure Control for a Hydraulic-Clutch-Brake-Combination actuated with a Linear Drive. 2010; 427-432.

http://ieeexplore.ieee.org/stamp/stamp.jsp?arnumber= 5472764

4. Ortlinghaus Group homepage. http://www.ortlinghaus.com/english/startseite.html

5. SHULER GmbH. Metal Forming Handbook. Springer 2012; 61-63; https://books.google.de/books?isbn=3642588573

6. Goizper - hydraulic clutch \& brake combination. http://rikind.com/sg/product-details/hydraulic-clutchbrake-catalog/

7. Technical documentation to tandem press line.

8. Szumera Jim. The metal stamping process: your product from concept to customer. 2002.

9. Federico Strasser. Metal stamping plant productivity handbook. 2007.
10. Metalworking Magazine. Mechanical press handbook: a basic handbook on the design and use of such presses, 26.07.2011.

11. E.W. Bliss Co, Power press handbook, 2007.

12. MetalForming magazine, Anthony Rante- Getting the Most from Mechanical Presses, 2017.

13. David Alkire Smith- Fundamentals of Pressworking, 1994.

14. Dennis Cattell- Stamping 101: Anatomy of a Mechanical Press, 2005.

15. Sawwa R, Dwojak S. The Flexible Robotization of the Press Line at the Car Factory Using the Industrial Controller, Turkey, 1990.

16. Tong Changhong, Zhang Zuopeng, Dong Shifang. Cause analysis and treatment on abnormal vibration for the pressmachine during working. 2016.

Received 2017-09-27

Accepted 2017-12-04

Available online 2017-12-18

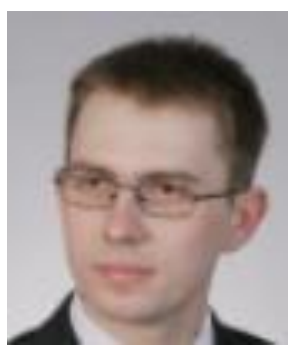

M.Sc., Eng. Krzysztof ROCZEK. He received the M.Sc. degree in 2010 on Silesian University of Technology and now he is actual working toward his $\mathrm{PhD}$ thesis. Since 2011 he Has been working as Controls Engineer at press shop in General Motors Manufacturing Poland company (currently Opel Manufacturing Poland). His main research interests includes diagnostic of electrical elements and industrial networks.

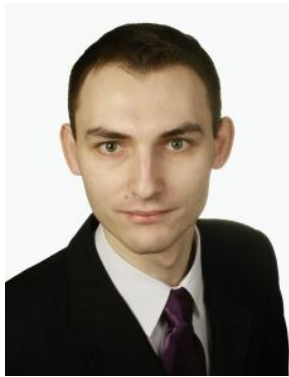

M.Sc., Eng. Adrian KROL. He received the M.Sc. degree in 2015 and now he is actual working toward his $\mathrm{PhD}$ thesis. He is a member of the Institute of Fundamentals of Machinery Design on Faculty of Mechanical Engineering, Silesian University of Technology. His main research interests include diagnostic process of large mechanical objects. 